\title{
Development of a New Steel Moment Connection
}

\author{
Xin Qian, Abolhassan Astaneh-Asl \\ University of California at Berkeley \\ 781 Davis Hall, Berkeley, CA, 94720-1710, USA \\ astaneh@berkeley.edu
}

\begin{abstract}
Steel moment frames are widely used in buildings subjected to lateral loads such as wind and earthquakes. This paper summarizes development of a new economical steel moment connection for use in highly seismic areas. The highly ductile new connection is primarily utilizing ductility of the gusset plate to provide necessary rotational capacity while the entire beam and column being connected remain essentially elastic. Due to the desirable performance of the connection and the flat geometry of the gusset plate, the proposed connection is well-suited to be used in steel and composite special ductile moment frames, special steel shear walls and dual systems of moment frames plus special concentrically braced frames, all currently used in seismic lateral force resistance in buildings. The proposed new moment connection can also be used in resisting gravity loads and lateral forces due to wind. In the proposed gusset plate moment connection, the beam is cut short to leave a distance from the column face where yielding and plastic hinge formation are expected to occur primarily due to in-plane yielding of the gusset plate. The gusset plate can either be directly welded to the column or bolted to the column using an end plate. With careful proportioning and proper detailing, the beam is expected to remain essentially elastic during the cyclic loading and no, or minimum continuity plates will be required for the column panel zone. Extensive nonlinear finite element analyses have been conducted. The results indicated that the connection will be very ductile and performs in a very desirable manner when the moment capacity of the gusset plate divided by the moment capacity of the beam ratio is less than 1.0, the thickness of the gusset plate is equal or greater than 1.25 times the beam web thickness and the free gusset plate length is equal to 4 to 6 times the gusset plate thickness. Based on the observation from the studies summarized herein, the use of "Upset bolts" is recommended for the bolted version, where tension bolts connect the gusset plate to the column.
\end{abstract}

Keywords: Structural Engineering, Steel Structures, Moment Connections, Earthquake Engineering, Seismic Design, Bolted Connections, Welded Connections.

\section{Introduction}

Steel moment frames are widely used in buildings subjected to lateral loads like wind and earthquake loads. Many different types and details of moment connections are available in the literature depending on the severity of the imposed loads - in the U.S.; it is categorized into Wind and Low Seismic Applications, where ductility requirements are less stringent, and High-Seismic Applications, where there is a high ductility demand. Design of steel moment connections changed significantly after the 1994 Northridge earthquake, when a number of field-welded steel moment connections were damaged in the form of fracture of the beam-to-column connections welds or areas of the beam and/or column adjacent to the weld. Based on the results of SAC Joint Venture Steel Project and other research effort, a series of recommendations were made to improve the connection design and performance in high seismic applications, the most important one being the higher ductility requirement for the connection as a whole and its elements. The SAC project also resulted in the development of several Prequalified steel moment connections that were validated by analysis and testing to have the necessary strength, stiffness and especially ductility. Fig.1 (a) shows typical Pre-Northridge earthquake connections that experienced damage during the 1994 Northridge earthquake in Los Angeles. Fig. 1(b), (c), and (d) show examples of Pre-qualified connections developed after the Northridge earthquake that are currently used in seismic design for high seismic applications.

The innovative ductile Special Gusset Plate Moment (SGPM) connection publicly presented in this paper for the first time, originated from a much larger on-going research projects by the authors to develop new and efficient steel plate shear wall systems. As mentioned earlier, the proposed connection not only can be used very efficiently in Steel Plate Shear Walls, but also in other steel and composite ( steel+ concrete) building structural systems such as the Special Moment Frames and dual system of Special Moment Frame plus Special Concentrically Braced Frames. 


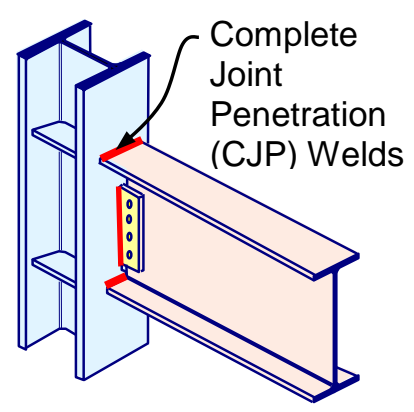

(a) Welded Flange

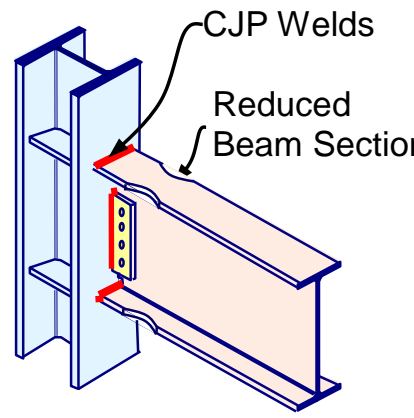

(b) Reduce Beam Section

(Pre-Northridge)

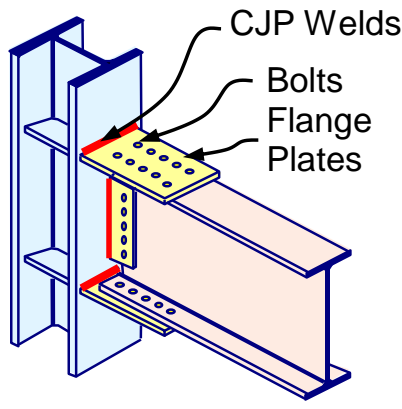

(c) Bolted Flange Plate

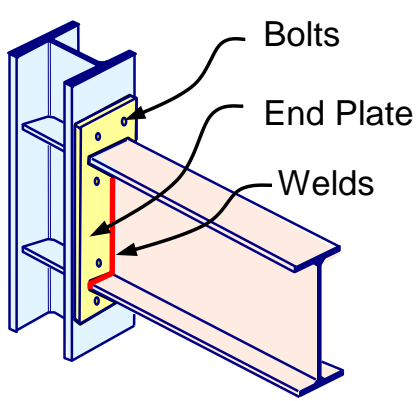

(d) End Plate

Fig. 1:(a) Pre-Northridge low-ductility steel moment connection and (b) through (d), examples of ductile Pre-qualified moment connections developed after Northridge earthquake ([1]).

\section{Brief Literature Review}

As summarized by Mahin [2] in 1998, the efforts after the 1994 Northridge earthquake to modify severely damaged pre-Northridge field-welded steel moment connections, shown in Fig. 1(a), were aimed at relocating plastic hinge in the girder away from the face of the column and the Complete Joint Penetration (CJP) welds connecting the beam to the column. This was accomplished either by reducing the beam section, Fig. 1(b) or, as shown in Fig. 1(c) and (d), by strengthening the connection such that the connection is stronger than the beam in bending, forcing the beam to be the "weak" link to form the plastic hinge in the beam. As shown in Fig.2, the strengthening approach may be accomplished by adding cover or side plates, vertical fins, haunches and knee braces or using stiffened extended end plate connection. Weakening approach has involved the reduction of the area of beam flanges by cutting the width of the flange, Fig. 1(b) or also by drilling holes. A relatively thorough review of the approaches and testing programs for the modification of existing welded steel moment frame connections can be found in references [3] and [4]. Note that by moving the plastic hinge in the beam away from the column and towards the mid-span of the beam increases the plastic hinge rotation demands as well as the bending moment acting on the column face. This can result in larger demands on the panel zone and column and require using horizontal continuity plates in the column, which a relatively costly construction and fabrication activity [2].

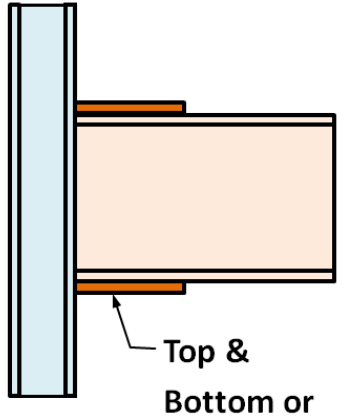

Side Plates

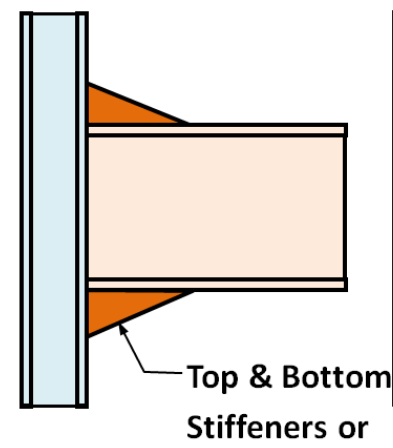

Brackets

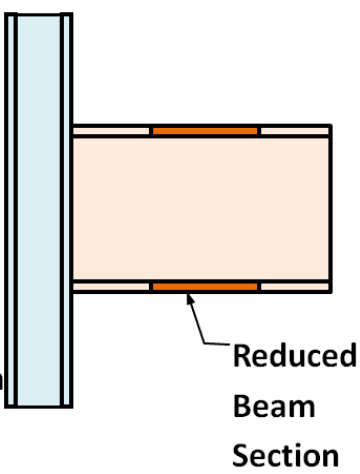

Section

Fig. 2: Typical approaches for modifying connections to move plastic hinge away from the column face.

\section{Objectives}

The main objective of the research project summarized here was to develop a new economical type of steel moment connection that uses the highly ductile yielding of gusset plates as the primary source of rotational ductility for the connection. Such connection can be used not only in ductile steel moment frames but also in ductile steel plate shear walls as well as in ductile dual systems consisting of moment frames and concentrically braced frames. 


\section{Proposed Concept}

In the proposed gusset plate moment connection, the beam is cut short to leave a distance from the column face. Yielding and plastic hinge formation is expected to occur primarily due to in-plane yielding of the gusset plate. The gusset plate can either be connected to the column face by weld or by bolts with end plate as shown in Fig. 3 .

For the welded option, the gusset plate will be welded to the column face in shop, and the beam to be fit in and welded to the gusset plate by either fillet weld or partial joint penetration (PJP) weld in field. For relatively thick gusset plate, complete joint penetration (CJP) weld may be required. For the bolted option, the gusset plate stem will be welded to the beam in shop with fillet or PJP welds, and bolt holes drilled in the gusset flange. Corresponding bolt holes in the column flange will also be prepared before transporting to the field. Then the pre-fabricated gusset plus beam module can be bolt connected to the column in field. The proposed connection design can avoid the use of complete joint penetration (CJP) welds and corresponding required inspection with ultra-sonic sound testing for gusset plate with thin or common thickness. After discussion with steel manufacturers, other methods are also possible to connect the beam to the gusset plate, for example, by using welded or bolted slotted connection plates. Fig. 4 shows examples of other possible details for the proposed gusset plate moment connection.

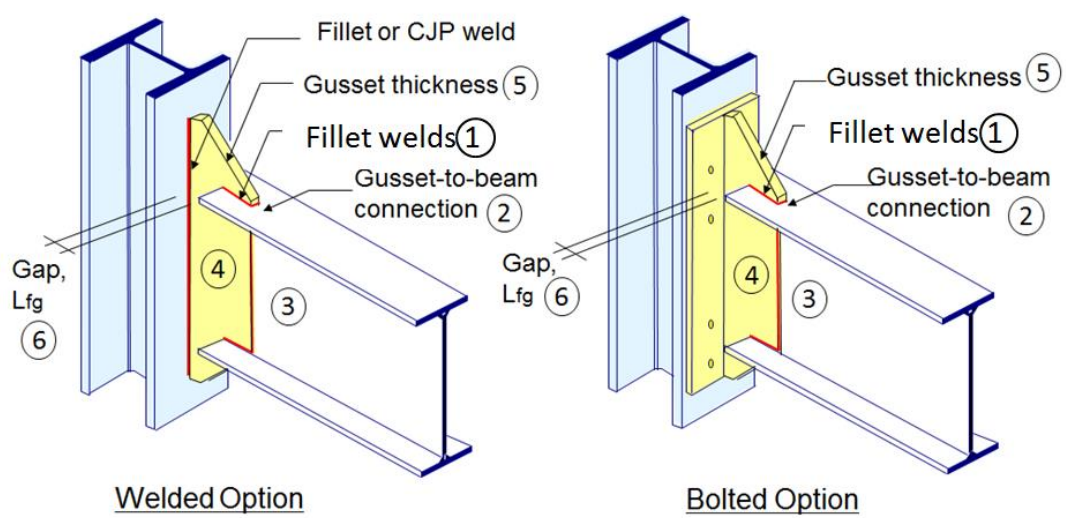

Fig. 3: Illustration of the proposed gusset plate moment connection.
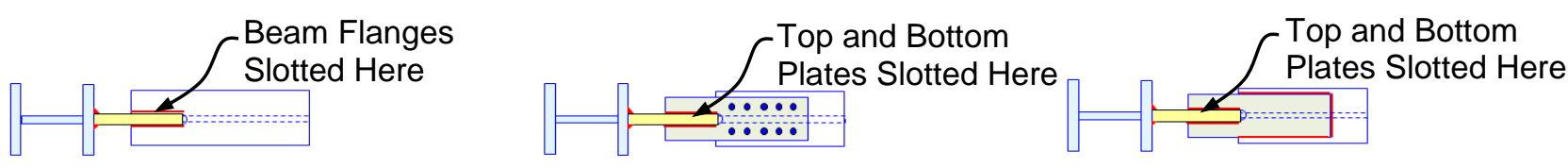

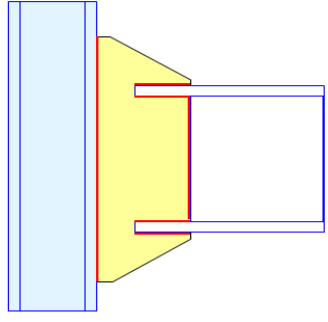

(a) Welded Slotted Beam

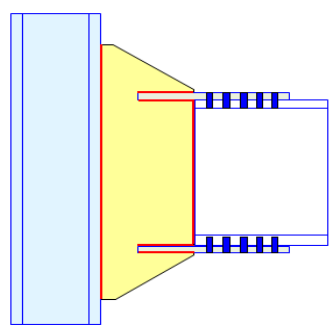

(b) Bolted Slotted Top-andBottom Plates

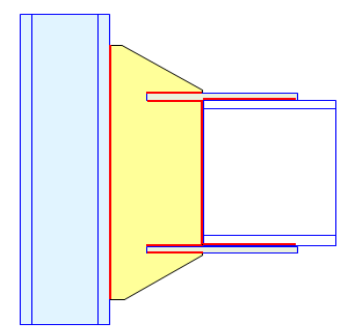

(c) Welded Slotted Top-andBottom Plates

Fig. 4: Other feasible details for the proposed gusset plate moment connection currently under development by authors.

The proposed configuration, by appearance, is analogous to the stiffened extended end-plate moment connection, except a gap is designed between the end of the beam and the column face, which brings in additional ductility and energy dissipation capability to the system. More importantly, unlike the stiffened end plate connection and all current prequalified connections, which have plastic hinge forming in the beam, in the proposed new Special Gusset Plate Moment Connection 
(SGPMC), the plastic hinge forms in the gusset plate and not in the beam. This results in the beam not being the inelastic element of the seismic force resisting system, thus, not requiring the very stringent limitations on the slenderness of its web and flanges to prevent local buckling. In essence, the design philosophy of the proposed new gusset plate moment connection can be looked at as being similar to the design philosophy of the reduced beam section (RBS) moment connection shown in Fig. 1(b) earlier. In both cases, instead of designing the connection to be stronger than the member, as is the case for connections in Fig. 1(c) and (d), the beam is designed to satisfy the gravity load strength demand and lateral load stiffness demand and the gusset plate connection is designed to satisfy seismic strength and ductility demand, and acts as a fuse.

The major difference between the proposed moment connection and the reduced beam moment connection or other Pre-qualified moment connections currently in use is that, instead of moving the plastic hinge away from the column and into the beam, in the proposed new gusset plate moment connection, the plastic hinge location is moved closer to the face of the column and forms inside the ductile element of connection, which is the gusset plate. As a result, the beam can be designed to remain elastic during the cyclic loading and the column web will not experience very high stresses in the panel zone area since yielding of the beam and the column is prevented by the yield capacity of the gusset plate which acts as an inelastic fuse. Another advantage of the proposed gusset plate moment connection is that the gusset plate transfers the bending moment at the end of the beam directly to the column web, instead of column flanges as is the case for other currently available moment connections. This is due to the fact that both gusset plate and column web are in the same vertical plane. This allows no, or minimum continuity plates to be needed for the column to protect the column flanges from distortion as is the case for other moment connections.

\section{Nonlinear Finite Element Analyses}

\subsection{Modelling Material and Geometry}

Four-node SHELL181 element from the ANSYS Shell element library were used to model all components in the beam-to-column connection subassemblies. Since the development of the proposed gusset moment connection was originally inspired by the ongoing study of the steel plate shear wall system by the authors, the mesh refinement study and material properties are based on information in reference [5]. Plasticity with multi-linear kinematic hardening material model was used to better capture the Bauchinger effect. Ramberg-Osgood material model was applied to define the entire stress-strain relationship, which was found to be able to better represent the strain hardening behavior observed in the test in reference [5]. For the bolted gusset plate moment connection option shown in Fig. 3(b) earlier, the bolts were modeled with beam element BEAM188 of ANSYS, with bilinear kinematic hardening material model and frictional contact element with coefficient of friction of 0.20 between the gusset plate assembly and the column flange surfaces. Residual stress and initial imperfection were not included in the model during the development of the proposed connection presented in this paper. It is believed that such minor imperfections do not have noticeable effect on inelastic behavior of connections.

\subsection{Simulation Set-up}

A typical beam-to-column sub-assembly was developed using the SC4T specimen dimensions in ref [5] as shown in

Fig.5. The loading history is created based on the ATC-24 loading protocol for stepwise increasing cyclic tests.
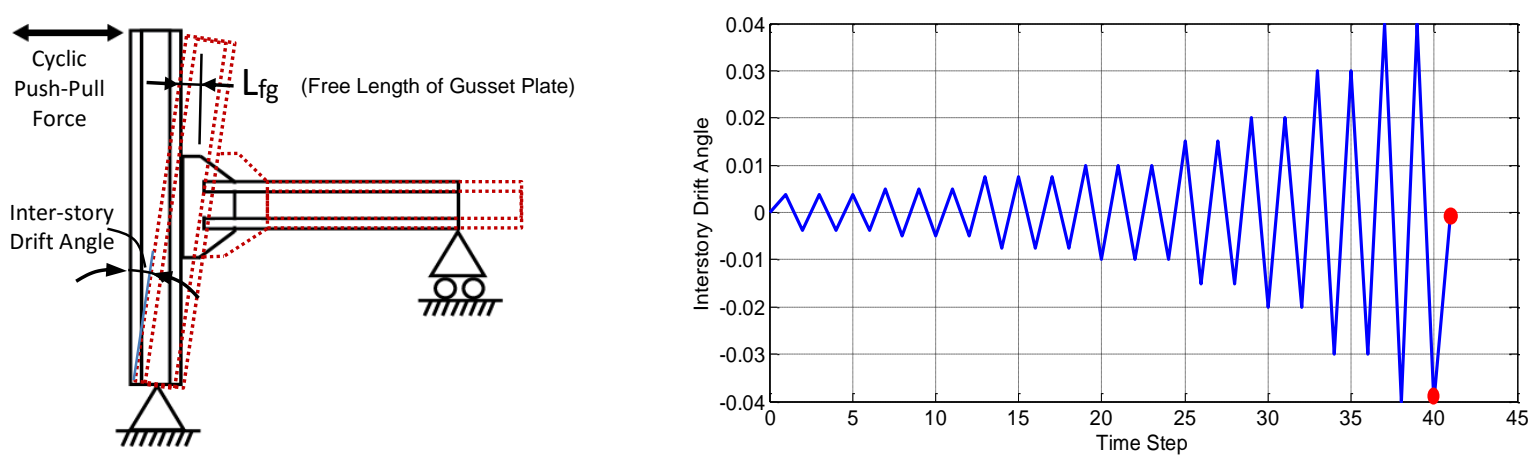

Fig. 5: Details of test set-up showing the boundary condition for the connection subassembly and the loading history. 


\section{Results}

\subsection{Behaviour of Gusset Plate Moment Connection}

\section{a. Comparison of proposed welded and bolted connections}

First we simulated four different configurations of our proposed gusset plate connections which included (a) welded option with $1.0 \mathrm{t}_{\mathrm{bw}}$ gusset plate thickness (b) welded option with $1.5 \mathrm{t}_{\mathrm{bw}}$ gusset plate thickness (c) bolted option with $1.0 \mathrm{t}_{\mathrm{bw}}$ gusset plate stem thickness (with bilinear bolt model) (d) bolted option with 1.0t $\mathrm{t}_{\mathrm{bw}}$ gusset plate stem thickness (bilinear bolt model $+70 \%$ pretension).

The hysteretic loops for four connections are plotted in Fig. 6. For welded connections ( top row in Fig. 6), it can be seen that assuming the welds are strong and ductile enough, the welded option showed stable and stocky hysteresis loops with relatively large energy dissipation for both cases of gusset plate thickness. With larger gusset thickness (i.e. $t_{\mathrm{g}}=1.5 \mathrm{t}_{\mathrm{bw}}$ ), the maximum peak value of the reaction force increased by about $38 \%$ compared to the case, when the thickness of the gusset was equal to the thickness of the beam web (i.e. $t_{\mathrm{g}}=1.0 \mathrm{t}_{\mathrm{bw}}$ ). The increase in the capacity is slightly less than the percentage of increase in the thickness, which was $50 \%$.

For bolted connections, as shown in the bottom row of Fig. 6, hysteresis loops were pinched and have lower energy dissipation capacity, which is to great extent because of insufficient number of bolts used in the models. This problem could possibly be resolved by redesigning the bolts such that they remain elastic throughout the cyclic loading. The pinching of hysteresis loops can also be reduced by making the flange of the gusset plate thicker. It should be noted that even though less energy can be dissipated due to pinched hysteresis loops, at the same force level, the bolted option could provide larger deformation, making the connection more ductile. Also, parameters not included in the modelling, such as the bolt slippage can result in increased ductility of the connection. Finally, with bolt pre-tension, the unloading branch becomes less smooth and less curved. The reason could be the additional linearity of bolt pretension brought into the connection. Since bolts connecting the gusset to the column are under combined tension and shear forces, the use of "Upset bolts" is recommended. In Upset bolts, the diameter of shank is less than the diameter of the threaded part to force yielding of unthreaded part of the bolt to occur prior to fracture of the threaded parts to ensure ductility and avoid fracture of the bolt.

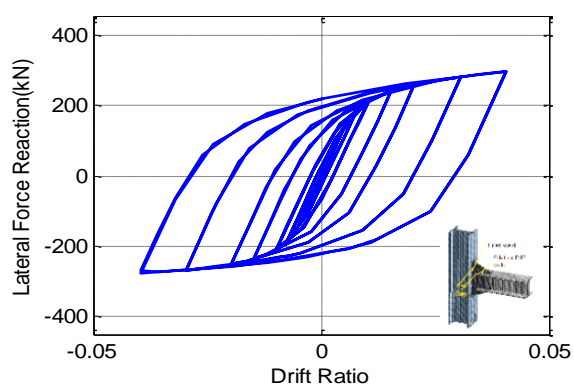

(a) Welded Option, $t_{a}=$

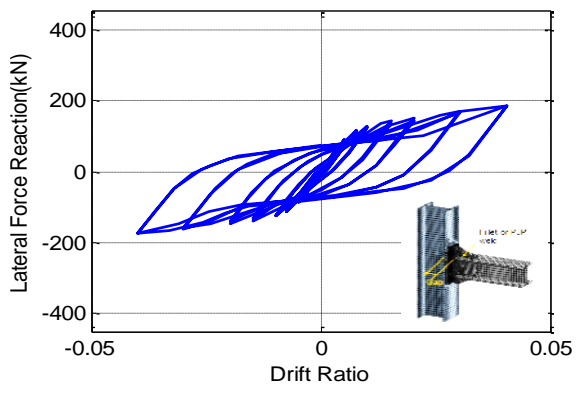

(c)Bolted Option, $\mathrm{t}_{\mathrm{g}}=\mathrm{t}_{\mathrm{bw}}$ (bolts not pre-tensioned)

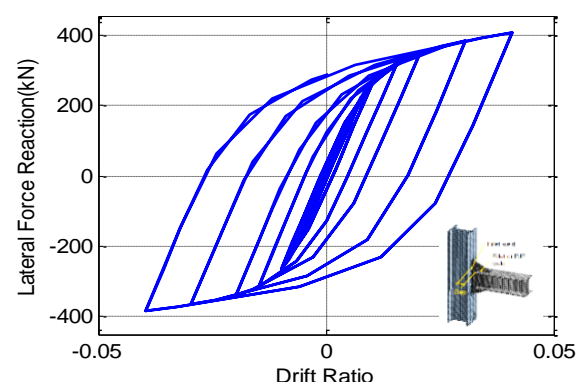

(b) Welded Option, $\mathrm{t}_{\mathrm{g}}=1.5 \mathrm{t}_{\mathrm{bw}}$

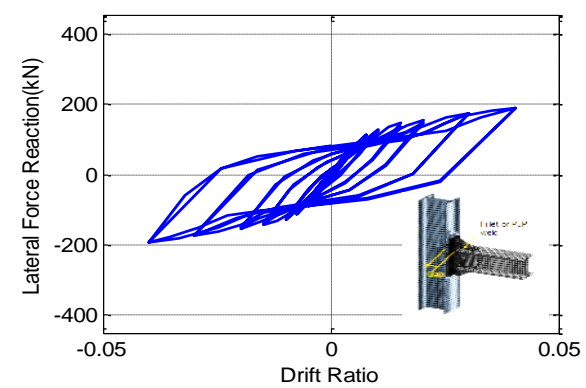

(d) Bolted Option, $t_{a}=t_{b w}$ (bolts pre-tensioned)

Fig. 6: Hysteresis loops of gusset beam-to-column connection sub-assembly. 


\section{b. Effect of gusset-to-beam plastic moment capacity ratio}

It is known that the ratio of the connection plastic moment capacity, $\mathrm{M}_{\mathrm{pc}}$, to the beam plastic moment capacity, $\mathrm{M}_{\mathrm{pb}}$, defines the inelastic performance of the beam-to-column connection. If the ratio of $\mathrm{M}_{\mathrm{pc}} / \mathrm{M}_{\mathrm{pb}}$ is greater than one, i.e. strong connection-weak beam case, the plastic hinge is expected to form in the beam. On the other hand if $\mathrm{M}_{\mathrm{pc}} / \mathrm{M}_{\mathrm{pb}}$ ratio is less than one, the plastic hinge is expected to form in the connection. To study the effect of ratio of $\mathrm{M}_{\mathrm{pc}} / \mathrm{M}_{\mathrm{pb}}$ on the cyclic behaviour of our proposed connection, we analysed the inelastic cyclic behaviour of five gusset plate moment connections with different $\mathrm{M}_{\mathrm{pc}} / \mathrm{M}_{\mathrm{pb}}$ ratios. The cases are shown in Table 1. To isolate the effect of this parameter, we kept the geometry of all study connections the same but in order to change only the plastic moment capacities; we used different yield stresses for the material. The pushover curves in Fig.7 (a) indicate that the moment capacity ratio does not have a significant effect on the overall stiffness and load carrying capacity of the moment frame having these connections. On the local level as Fig.7 (b) shows, important differences in the connection behaviour exist. For $\mathrm{M}_{\mathrm{pc}} / \mathrm{M}_{\mathrm{pb}}<1$, almost all inelastic deformation is concentrated in the gusset plate while the beam remains elastic. However, for $\mathrm{M}_{\mathrm{pc}} / \mathrm{M}_{\mathrm{pb}}>1$, relatively large areas of the beam yield, which is not as desirable as beam remaining elastic. Therefore, in order to fully achieve the goal of the proposed concept, it is important to keep the plastic moment capacity ratio $\mathbf{M}_{\mathrm{pc}} / \mathrm{M}_{\mathrm{pb}}$ below one, making it a strong semi-rigid connection.

Table 1: Effect of gusset-to-beam plastic moment capacity ratio.

\begin{tabular}{|l|l|l|l|l|l|l|}
\hline Case & Name & $\begin{array}{l}\text { Column } \\
\text { yield } \\
\text { stress, } \\
\text { MPa }\end{array}$ & $\begin{array}{l}\text { Plate } \\
\text { yield } \\
\text { stress, } \\
\text { MPa }\end{array}$ & $\begin{array}{l}\text { Beam } \\
\text { yield } \\
\text { stress, } \\
\text { MPa }\end{array}$ & $\begin{array}{l}\text { Gusset } \\
\text { Yield Stress, } \\
\text { MPa }\end{array}$ & $\mathbf{M}_{\mathbf{p c}} / \mathbf{M}_{\mathbf{p b}}$ \\
\hline $\mathbf{1}$ & B50/G50 & 450 & 345 & 345 & 345 & $\mathbf{0 . 8 8}$ \\
\hline $\mathbf{2}$ & B50/G70 & 450 & 345 & 345 & 485 & $\mathbf{1 . 2 4}$ \\
\hline $\mathbf{3}$ & B65/G70 & 450 & 345 & 450 & 485 & $\mathbf{0 . 9 5}$ \\
\hline $\mathbf{4}$ & B65/G50 & 450 & 345 & 450 & 345 & $\mathbf{0 . 6 8}$ \\
\hline $\mathbf{5}$ & B65/G65 & 450 & 345 & 450 & 450 & $\mathbf{0 . 8 8}$ \\
\hline
\end{tabular}

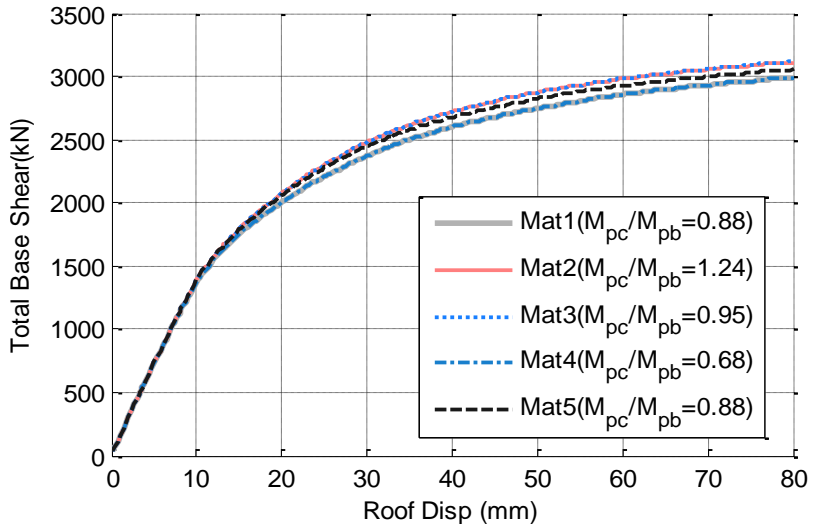

(a)

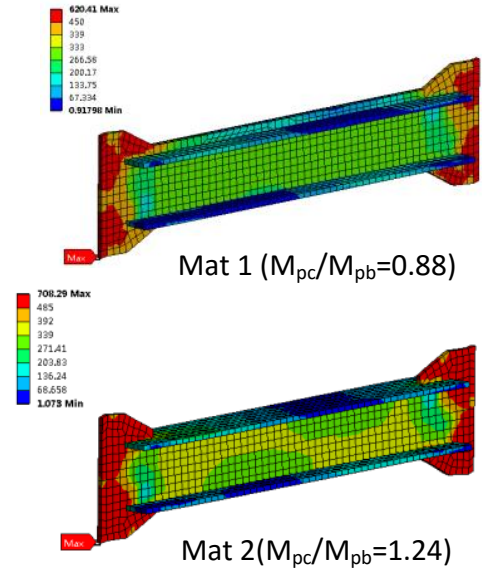

(b)

Fig. 7: (a) Comparisons of pushover curves for different $M_{p c} / M_{p b}$; and (b) Illustration of yielding region for $\mathrm{M}_{\mathrm{pc}} / \mathrm{M}_{\mathrm{pb}}<1$ and $\mathrm{M}_{\mathrm{pc}} / \mathrm{M}_{\mathrm{pb}}>1$.

\section{Effect of shape of the gusset plate}

To understand the effects of the shape of gusset plate on the behaviour of proposed gusset plate moment connection, we studied a variety of geometries for the gusset plate. The results of von Mises stresses are shown in Fig. 8. First, a 
rectangular gusset plate of dimension $394 \mathrm{~mm}$ by $210 \mathrm{~mm}$ was analysed. The plot of von Mises stresses showed that the yielded region is roughly in the form of two intersected "bell" shapes, similar to Whitmore's areas [6], around the roots of the gusset-to-beam flange connection, while the areas of the gusset plate outside this highly stressed areas show not much of stress. For this rectangular gusset plate, the maximum plastic strain occurred at the intersection of the vertical side to the beam flange (Fig.8 Case Rect 1 on top-left). Based on such observations, five other slightly modified gusset plate shapes were developed, mainly aiming to make more efficient use of the section following the stress distribution and reduce the strain concentrations. Case Rect 2 (top-right corner of Fig 8) was selected to study the size effect.

It was observed that peak stress/strain often occurs at three critical locations - root of the gusset horizontal side-tocolumn weld, root of gusset vertical side-to-beam flange weld, and root of mid gusset-to-beam flange edge (denoted as yellow dots in Fig.8). Larger gusset plates were found to provide more capacity but caused greater yielding in the columns and beams, which is undesirable. Gusset plate geometry Trap 2 was considered most efficient and desirable among the analysed geometries since the yielded point with maximum equivalent plastic strain for this case was located within the gusset plate surrounded by essentially elastic elements instead of yielded zone being at the free edge of the gusset plate. In a plate, whenever yielded elements are relatively small and are surrounded entirely by elastic elements, such yielding will remain confined and can be ignored. In addition, with the well-established Whitmore section for gusset plate design in braced frames [6] and [7], a value of 20 to 30 degrees for the angle of slope of gusset plate edge, $\theta$, is found to be appropriate for the proposed gusset plate beam-to-column moment.
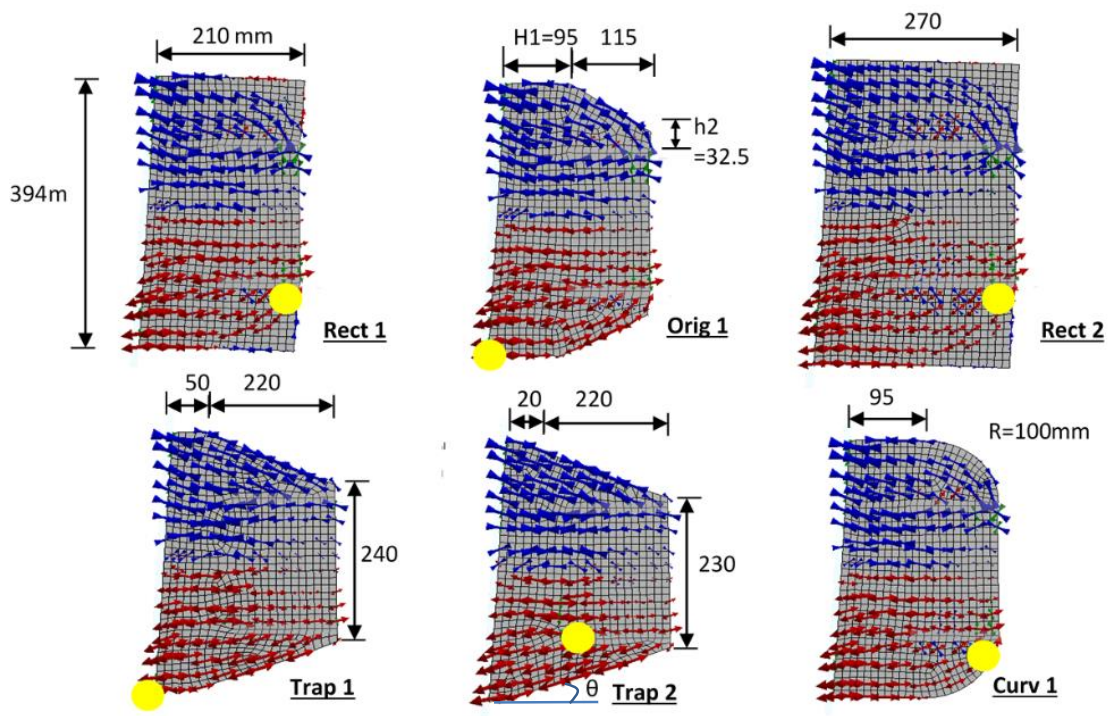

Fig. 8: Comparison of dimensions and of maximum equivalent plastic strain regions for different gusset plate shapes.

\section{d. Effect of thickness of the gusset plate}

Cases with gusset plate thickness being 1.0, 1.25 and 1.5 times the beam web thickness were analysed. Based on the cases analysed and to avoid large yielding in beam and column and gusset plate buckling, a gusset plate thickness of $\underline{1.25 \text { times }}$ the beam web is recommended to be used if the yield stresses of the gusset and beam material are the same.

\section{e. Effect of free gusset length}

The free gusset length of the gusset plate, $\mathrm{L}_{\mathrm{fg}}$, is defined as the distance between the end of the beam to the face of the column as was shown in Fig. 3 earlier. For the models simulated, $\mathrm{L}_{\mathrm{fg}}$ was varied as percentage of the beam depth $\mathrm{d}_{\mathrm{b}}(30 \%, 40 \%$, $47.5 \%, 60 \%$ and $75 \%$ ), which can also be expressed as multiples of gusset plate thickness $t_{g}$. For example, for $t_{g}$ equal to $t_{b w}$, the ratio $\mathrm{L}_{\mathrm{fg}} / \mathrm{t}_{\mathrm{g}}$ correspond to $4,5,6,7.5$ and 9 .

Fig. 9 shows that as the free gusset length decreases, regardless of the thickness of the gusset plate, the overall shear capacity of the beam-to-column connection increases and less out-of-plane deformation of the gusset plate was observed. By using a small $\mathrm{L}_{\mathrm{fg}}$, which is similar to the directly welded beam-to-column connection with triangular stiffening plates, the column 
web will be subjected to larger force due to gusset plate yielding. From the parametric study, the preferred value for free length, $\mathrm{L}_{\mathrm{fg}}$, for the gusset plate is 4 to 6 times the thickness of the gusset plate. In addition to controlling the $\mathrm{L}_{\mathrm{fg}}$ and $\mathrm{t}_{\mathrm{g}}$ value to prevent the degradation of behaviour due to out-of-plane deformation of gusset plate, one may also consider to provide lateral support to the beam lower flange if possible.
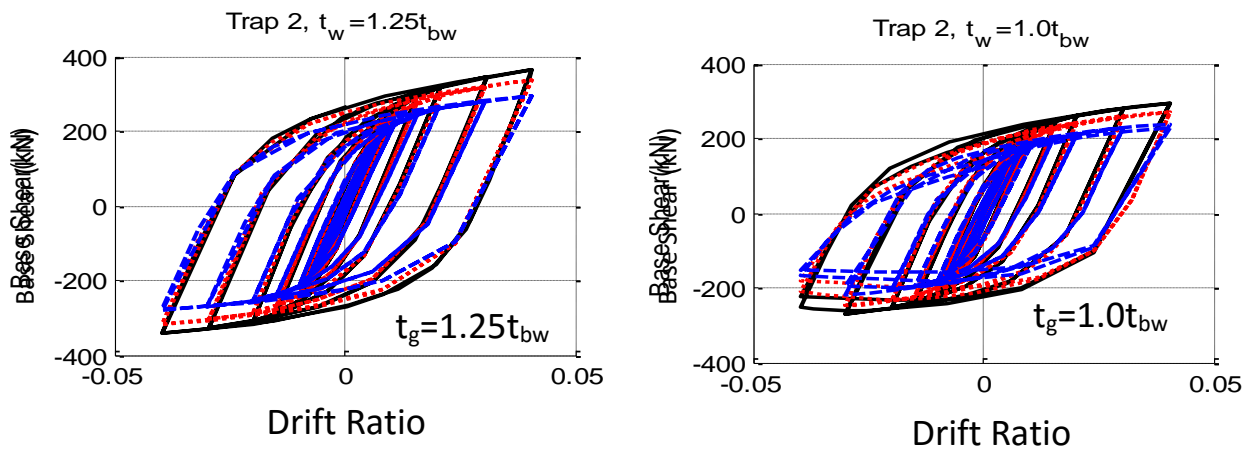

F安. 19. Comparison of cyclic hysteresis loops aqd gousset plate out-of-plane deformation.

\section{Conclusion}

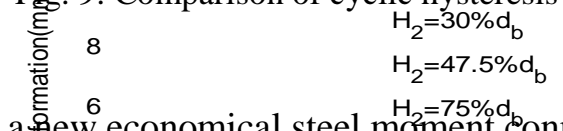

In conclusion, a proposed in this paper. The use of gusset plate and the proposed cyclic loading while a a fost all of the inelastic deformation and continuity plates will be required for the column panel zone due formation of plastic hinge in the gusset plate close to the column face. With the flat-gosset plate, the proposed conmestion can force resisting system. The proposed gussisteßptiate innovative moment connection exif a assio be efficiently used in a dual system of special concentrically braced frames combined with moment frames.

Based on nonlinear finite element analyses, key observations and recommendations are: 1) the gusset-to-beam moment capacity ratio should be kept smaller than one, 2) a gusset thickness of 1.25 times the beam web thickness and a free gusset length of 4 to 6 times the gusset thickness are recommended, and 3) use of upset bolts is suggested for the bolted option to increase ductility of bolts that are in tension.

\section{Acknowledgements}

This study was part of a larger project on "Investigation of Seismic Performance of Moment Frames and Steel Shear Walls" at the University of California Berkeley, USA, with Prof. Abolhassan Astaneh-Asl as the Principal Investigator. The authors would like to express their sincere appreciation for the tremendous technical support provided by Dr. Metin Ozen, President as well as Casey Heydari, and the analysts at Ozen Engineering Inc. (https://www.ozeninc.com/) on the use of the powerful ANSYS nonlinear structural analysis software featured in this project. The authors also wish to thank Mr. Brett Manning, Vice President Northwest Sales / Engineering, Schuff Steel for his valuable technical advice in developing the new innovative steel moment connection.

\section{References}

[1] A. Astaneh-Asl, "Behavior and Design of Steel Structures," Fall 2015 Ed., 2015.

[2] S. A. Mahin, "Lessons from Damage to Steel Buildings during the Northridge Earthquake," Engineering Structures, vol. 20, no. 4-6, pp. 261-70, 1998.

[3] SAC Joint Venture, "Interim guidelines: evaluation, repair, modification and design of welded steel moment frame structures," Report FEMA 267/SAC Report 95-02, Federal Emergency Management Agency: Washington DC, 1995.

[4] SAC Joint Venture, "Connection Test Summaries," Report FEMA 289/SAC Report 96-02, Federal Emergency Management Agency: Washington DC, 1997

[5] H. G. Park., et al., "Framed steel plate wall behaviour under cyclic lateral loading," Journal of structural engineering, vol. 133, no. 3, pp. 378-388, 2007.

[6] A. Astaneh-Asl, Seismic Behavior and Design of Gusset Plates. CA: Structural Steel Educational Council, 1998. 
[7] A. Astaneh-Asl, M. L. Cochran, and R. Sabelli, Seismic Detailing of Gusset Plates for Special Concentrically Braced Frames. CA: Structural Steel Educational Council, 2006. 